\title{
Synthesis and Evaluation of Ciprofloxacin-Nitroxide Conjugates as Anti-Biofilm Agents
}

\author{
Anthony D. Verderosa ${ }^{1}$, Sarah C. Mansour ${ }^{2}$, César de la Fuente-Núñez ${ }^{3,4,5,6}$, \\ Robert E. W. Hancock ${ }^{2}$ and Kathryn E. Fairfull-Smith ${ }^{1, *}$ \\ 1 ARC Centre of Excellence for Free Radical Chemistry and Biotechnology, Faculty of Science and Engineering, \\ Queensland University of Technology, Queensland 4001, Australia; a.verderosa@hdr.qut.edu.au \\ 2 Centre for Microbial Diseases and Immunity Research, Department of Microbiology and Immunology, \\ University of British Columbia, Vancouver, BC V6T 1Z4, Canada; sarah@hancocklab.com (S.C.M.); \\ bob@hancocklab.com (R.E.W.H.) \\ 3 Synthetic Biology Group, MIT Synthetic Biology Center, Massachusetts Institute of Technology, Cambridge, \\ MA 02139, USA; cfuente@mit.edu \\ 4 Research Laboratory of Electronics, Department of Biological Engineering, Department of Electrical \\ Engineering and Computer Science, Massachusetts Institute of Technology, Cambridge 02139, MA, USA \\ 5 Broad Institute of MIT and Harvard, Cambridge, MA 02142, USA \\ 6 Harvard Biophysics Program, Harvard University, Boston, MA 02115, USA \\ * Correspondence: k.fairfull-smith@qut.edu.au; Tel.: +61-7-3138-4950; Fax: +61-7-3138-1804
}

Academic Editor: Fawaz Aldabbagh

Received: 3 May 2016; Accepted: 21 June 2016; Published: 27 June 2016

\begin{abstract}
As bacterial biofilms are often refractory to conventional antimicrobials, the need for alternative and/or novel strategies for the treatment of biofilm related infections has become of paramount importance. Herein, we report the synthesis of novel hybrid molecules comprised of two different hindered nitroxides linked to the piperazinyl secondary amine of ciprofloxacin via a tertiary amine linker achieved utilising reductive amination. The corresponding methoxyamine derivatives were prepared alongside their radical-containing counterparts as controls. Subsequent biological evaluation of the hybrid compounds on preformed P. aeruginosa flow cell biofilms divulged significant dispersal and eradication abilities for ciprofloxacin-nitroxide hybrid compound 10 (up to $95 \%$ eradication of mature biofilms at $40 \mu \mathrm{M}$ ). Importantly, these hybrids represent the first dual-action antimicrobial-nitroxide agents, which harness the dispersal properties of the nitroxide moiety to circumvent the well-known resistance of biofilms to treatment with antimicrobial agents.
\end{abstract}

Keywords: radical; antibiotic; biofilm; nitroxide; ciprofloxacin

\section{Introduction}

The adhesion of planktonic bacterial cells to a surface in the presence of the appropriate environmental cues often results in the formation of a complex bacterial community known as a biofilm. Biofilms represent a significant problem for almost all healthcare systems around the world [1-3], mainly due to their ability to colonize indwelling medical devices [4] and chronic wounds [5]. A large proportion (approximately 80\%) of all microbial-based infections present in humans [6] are caused by biofilms. Although numerous antimicrobial treatments exist for the effective eradication of planktonic bacteria, these approaches are generally ineffective when implemented against biofilms [7,8], which have been shown to be extremely resistant to antibiotic therapies $[6,9,10]$. Consequently, the development of novel strategies for the effective treatment of mature biofilms is urgently required.

Although the natural mode of bacterial growth is well known to be predominately as a biofilm, it is also understood that the bacterial population can alternate between the planktonic and biofilm 
lifestyles by varying the expression of particular genes [11]. Hence, an emerging strategy to combat bacterial biofilms is to use small molecules that act through non-microbicidal mechanisms to inhibit and/or disperse bacterial biofilms [12,13]. The free radical gaseous molecule, nitric oxide (NO), has been identified as an important signaling molecule in a variety of biofilm-forming species [14] as it is capable of mediating both biofilm formation and dispersal [15-17]. Nitric oxide can induce a transition from the sessile biofilm mode of growth to a dispersed (planktonic) state when utilised at low, sub-lethal concentrations (in the $\mathrm{pM}$ to low nM range) $[14,16]$. Interestingly, differences in the phenotypes of dispersed and planktonic cells have been recently reported in P. aeruginosa [18]. The observed effect of $\mathrm{NO}$ on biofilms has been associated with a reduction in the intracellular levels of the secondary messenger cyclic di-GMP, which plays a key role in biofilm development $[11,19]$.

The implementation of nitric oxide as an anti-biofilm agent is significantly hindered by its extreme chemical reactivity and short half-life (between 0.1-5 s) [20]. Thus, as a means to avoid the challenges associated with handling and/or delivering nitric oxide into systems where biofilms are prevalent, the use of nitric oxide-donor molecules [21] have been investigated and comprehensive reviews on the ability of NO-donor compounds to disperse bacterial biofilms have been recently documented [22]. Several new anti-biofilm compounds have also been developed, which incorporate NO donors such as cephalosporin-3'-diazeniumdiolate $\mathbf{1}$ (Figure 1) that only releases NO upon reaction with biofilm specific enzymes (e.g., $\beta$-lactamase) [23]. However, as NO-donor molecules are also often inherently unstable [24], the use of nitroxides, have more recently been examined as an alternative strategy for biofilm dispersal.

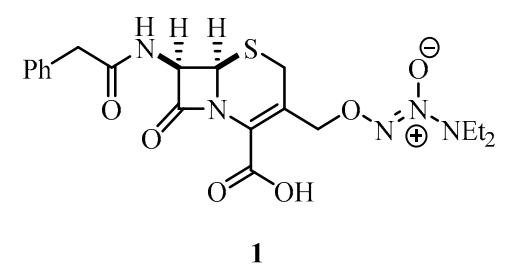

Figure 1. NO donor prodrug cephalosporin-3'-diazeniumdiolate $\mathbf{1}$.

Nitroxides are long-lived, stable free radical species that contain a disubstituted nitrogen atom bound to a univalent oxygen atom [25]. Nitroxides and nitric oxide are structurally similar compounds with both containing an unpaired electron, which is delocalized over the nitrogen-oxygen bond (Figure 2). Additionally, as both types of compounds are known to be efficient scavengers of protein-derived radicals, the biological effects of nitroxides can be explained by their nitric oxide-mimetic properties [26]. However, unlike nitric oxide, which at room temperature is a reactive gas, and relatively unstable, nitroxides are generally air-stable crystalline solids. Nitroxides can also undergo redox chemistry and it has been previously hypothesized that their antibacterial activity may result from their oxidation by reactive oxygen species to oxoammonium ions which interact with bacterial cell membranes [27].

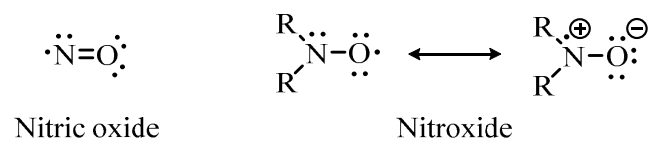

Figure 2. Structure of nitric oxide and the general structure of a nitroxide.

We have previously established that nitroxide-containing compounds can mimic the dispersal behavior of nitric oxide towards Pseudomonas aeruginosa biofilms grown in flow cell chambers [27]. At concentrations of $20 \mu \mathrm{M}$, nitroxides were shown to both inhibit P. aeruginosa biofilm formation, and trigger the dispersal of mature biofilms. Furthermore, these compounds were able to restore swarming motility in a nitrite reductase deficient mutant strain of $P$. aeruginosa, indicating that they were acting in a similar manner to nitric oxide and were able to enter bacterial cells. The effect of 
various nitroxides on biofilm dispersal has also been reported by others but at higher concentrations $(5 \mathrm{mM})$ using the less-sensitive crystal violet staining technique [28,29]. The anti-bacterial activity of nitroxide-coated silver nanoparticles has also been recently described, with the presence of the nitroxide unit shown to enhance the anti-bacterial properties of the silver nanoparticles [30]. Additionally, we have recently demonstrated that almost complete eradication of mature $P$. aeruginosa and E. coli biofilms can be achieved when biofilms are treated with a nitroxide in combination with an antibiotic (ciprofloxacin) [31]. These results suggest that the dispersal properties of nitroxides can be harnessed to circumvent the well-known resistance of biofilms to treatment with antimicrobial agents.

In the present study, we explored the possibility that a nitroxide and an antibiotic could be combined into a single molecule for the efficient treatment of biofilms. The rationale behind this approach was that the nitroxide would trigger the dispersal of cells from biofilms (that are resistant to antibiotic action), and the antibiotic would then be able to kill these dispersed bacteria, thus efficiently eradicating the biofilm. The use of a conjugate molecule in this strategy should optimize the anti-biofilm effect as the antibiotic would be located near the site of biofilm dispersal allowing it to act directly on the dispersed cell population before the bacteria returns to the preferred biofilm mode of growth.

Herein, we report the design and synthesis of several ciprofloxacin-nitroxide hybrid molecules and their evaluation as potential anti-biofilm agents to eradicate existing P. aeruginosa biofilms.

\section{Results and Discussion}

\subsection{Chemistry}

Ciprofloxacin 2 (Figure 3) is a fluoroquinolone antibiotic that acts by inhibiting the bacterial enzymes DNA gyrase (a type II topoisomerase) and topoisomerase IV, which are required for DNA replication $[32,33]$. Various structural modifications to the ciprofloxacin core have disclosed that the secondary amine of the piperazine ring at the 7-position represents a useful handle where further synthetic transformations can be performed without significantly affecting the antimicrobial activity of the molecule [34-36]. Furthermore, the addition of large substituents at the 7-position of fluoroquinolones does not adversely affect drug permeability through bacterial membranes [37] and the variety of piperazinyl substituents introduced at this position has revealed the looseness of the binding pocket of the targeted DNA gyrase [38-40].

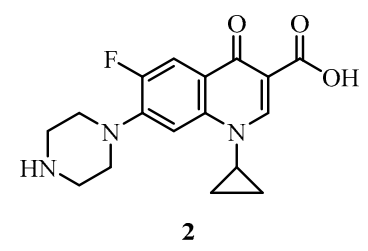

Figure 3. Ciprofloxacin 2.

For these reasons, we chose to generate our first generation of ciprofloxacin-nitroxide hybrids by tethering nitroxides to the secondary amine of the piperazine ring of ciprofloxacin, using reductive amination chemistry [41] to generate a ciprofloxacin-nitroxide conjugate connected via a tertiary amine linkage. The cyclic nitroxides 4-oxo-2,2,6,6-tetramethylpiperidin-1-yloxyl (TEMPONE) 6 and the more rigid 5-formyl-1,1,3,3-tetramethylisoindolin-2-yloxyl (FTMIO) 12 [42] were selected as the nitroxide coupling partners as both these nitroxide structures contain bis(tert-alkyl) groups on the carbon atoms $\alpha$ to the nitroxide, making them highly resistant to degradation through disproportionation [43]. In addition to this, both of the structural piperidine and isoindoline cores have been previously shown to possess dispersal activities in bacterial biofilms [27].

The reductive amination methodology was first optimized using TEMPONE 6 . To begin, the carboxylic acid of ciprofloxacin 2 was protected by conversion to the ethyl ester derivative 5, by following previously documented methodologies [44]. Using typical reductive amination conditions [45], 
a methanol solution of the protected ciprofloxacin 5 with TEMPONE 6 and acetic acid (4 equivalents) was treated with $\mathrm{NaBH}_{3} \mathrm{CN}$. Acetic acid is often used for reductive amination reactions with ketones to catalyze the formation of the imine intermediate [46]. $\mathrm{NaBH}_{3} \mathrm{CN}$ was employed as the reductant as it can selectively reduce imines in the presence of carbonyl groups [47].

After heating at $60^{\circ} \mathrm{C}$ for $5 \mathrm{~h}$, no starting material remained (TLC analysis) and the desired protected ciprofloxacin-nitroxide hybrid 8 could be isolated but only in a low yield (3\%). Two additional products, the alcohol derivative 4 (Figure 4) of 8 and 4-hydroxy-2,2,6,6-tetramethylpiperidin-1-yloxyl (TEMPOL) 3 (Figure 4) were also formed in the reaction and isolated in modest yields (23\% and $30 \%$ yield).

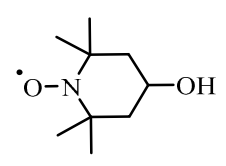

3

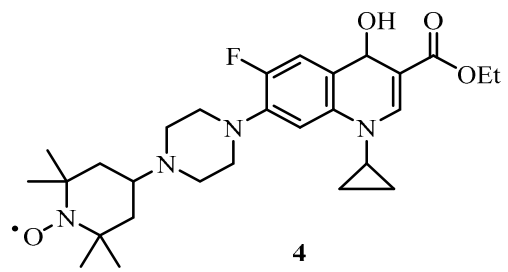

4

Figure 4. TEMPOL 3 and alcohol derivative 4 .

The reduction of the ketone at the 4-position of ciprofloxacin 2 by $\mathrm{NaBH}_{3} \mathrm{CN}$ has not been previously reported, but the reduction of ketones or aldehydes, to their corresponding alcohols, in the presence of $\mathrm{NaBH}_{3} \mathrm{CN}$ is well documented and reported to be highly $\mathrm{pH}$ dependent [48]. In acidic environments $(\mathrm{pH}<4)$, the reduction of ketones or aldehydes with $\mathrm{NaBH}_{3} \mathrm{CN}$ proceeds rapidly, while in slightly acidic to neutral environments ( $\mathrm{pH} \mathrm{6-7),} \mathrm{the} \mathrm{reduction} \mathrm{of} \mathrm{ketones} \mathrm{and} \mathrm{aldehydes} \mathrm{is}$ significantly slower. In either situation, however, the reduction of imines or iminium ions is known to be kinetically favored over the reduction of carbonyl groups $[47,48]$. Thus, the presence of the reduced products, TEMPOL 3 and the alcohol derivative of ciprofloxacin 4, indicate an excessively acidic reaction environment conducive to the rapid reduction of ketones. The formation of the desired product 8 and the alcohol derivative 4 indicates successful iminium ion production and subsequent reduction. However, it can be concluded that the rate of iminium ion formation must be significantly slower than the rate of ketone reduction under these conditions.

In order to circumvent the formation of the two undesired products, the reductive animation reaction was repeated using fewer equivalents of acetic acid ( 0.9 equivalents) and the iminium ion was generated by stirring at $60^{\circ} \mathrm{C}$ for $2 \mathrm{~h}$, prior to the addition of the reducing agent. Under these conditions, the desired ciprofloxacin-nitroxide hybrid 8 was isolated in reasonable yield (51\%) after stirring at $50{ }^{\circ} \mathrm{C}$ overnight (Scheme 1). These optimized conditions were then employed to generate the conjugate compound 14 (Scheme 2) in an isolated yield of 82\%. Final deprotection of ethyl esters (8 and 14) via base mediated hydrolysis produced the desired ciprofloxacin-nitroxide hybrids (10 and 16) in high yields (89\% and 80\% respectively, see supplementary materials for NMR and EPR spectra).

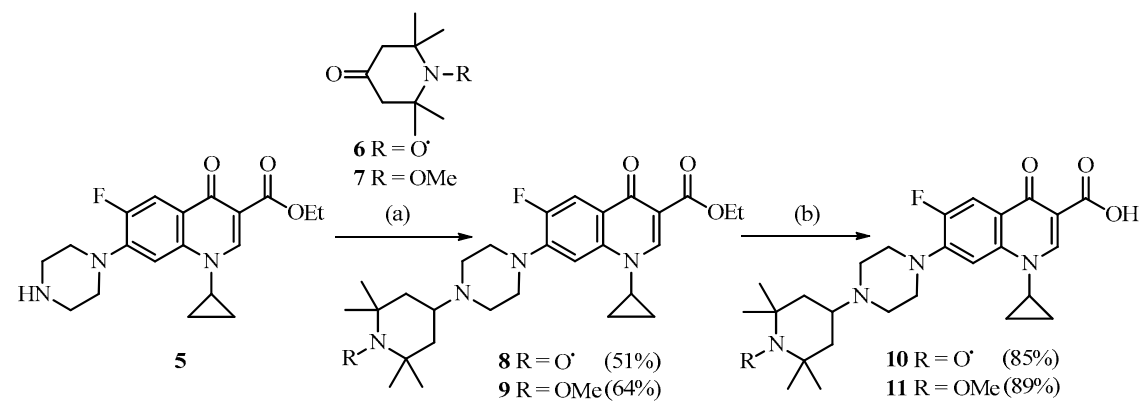

Scheme 1. Synthetic route to ciprofloxacin-nitroxide hybrid 10 and its corresponding methoxyamine derivative 11. Reagent and conditions: (a) (i) $\mathrm{AcOH}, \mathrm{MeOH} 60^{\circ} \mathrm{C}, 2 \mathrm{~h}$. (ii) $\mathrm{NaBH}_{3} \mathrm{CN}, 50{ }^{\circ} \mathrm{C}, 24 \mathrm{~h}$; (b) $2 \mathrm{M} \mathrm{NaOH}, \mathrm{MeOH}, 50{ }^{\circ} \mathrm{C}, 5 \mathrm{~h}$. 


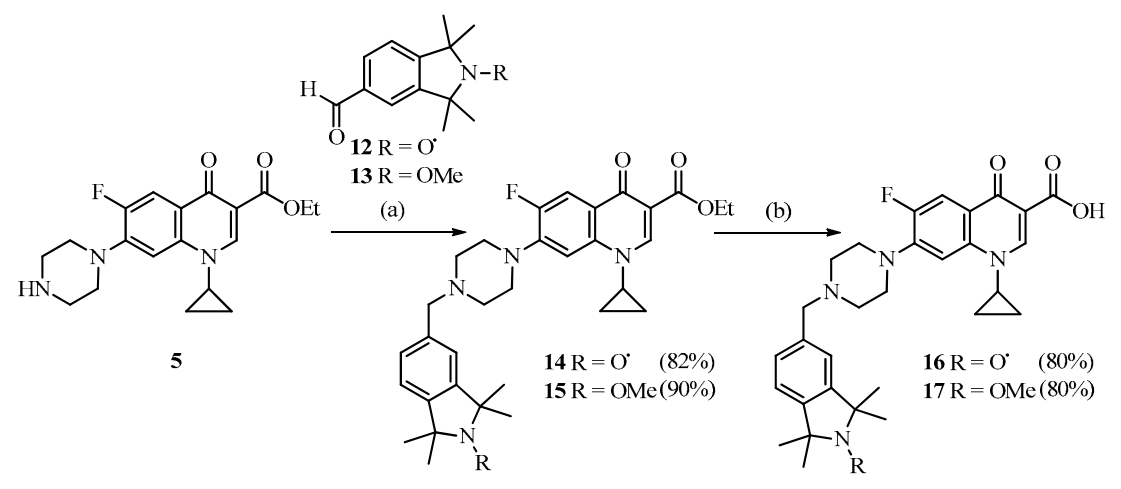

Scheme 2. Synthetic route to ciprofloxacin-nitroxide hybrid 16 and its corresponding methoxyamine derivative 17. Reagent and conditions: (a) (i) $\mathrm{AcOH}, \mathrm{MeOH} 60^{\circ} \mathrm{C}, 2 \mathrm{~h}$. (ii) $\mathrm{NaBH}_{3} \mathrm{CN}, 50{ }^{\circ} \mathrm{C}, 24 \mathrm{~h}$; (b) $2 \mathrm{M} \mathrm{NaOH}, \mathrm{MeOH}, 50{ }^{\circ} \mathrm{C}, 5 \mathrm{~h}$.

In addition to the generation of the novel ciprofloxacin-nitroxide hybrids (10 and $\mathbf{1 6})$, their methoxyamine derivatives (11 and $\mathbf{1 7})$ were also synthesised. These derivatives (11 and $\mathbf{1 7})$ were prepared as control compounds to enable a direct comparison of the biofilm dispersal effect of the nitroxide moiety. The methoxyamine functionality was introduced to the ketone and aldehyde functionalized nitroxides (6 and 12) utilising well-known Fenton chemistry [49]. The nitroxides (6 and 12) were treated with methyl radicals generated from hydrogen peroxide, iron(II) sulphate heptahydrate and DMSO [50] to furnish methoxyamines (7 and 13) in excellent yields (83\% and $91 \%$ respectively). Reductive amination of methoxyamine derivatives ( 7 and 13$)$ with the protected ciprofloxacin 5 utilising the methodology documented above gave the protected ciprofloxacinmethoxyamine conjugates (9 and 15) in good yields (64\% and 90\%, respectively). Subsequent ethyl ester deprotection of $\mathbf{9}$ and $\mathbf{1 5}$ generated the desired ciprofloxacin-methoxyamines (11 and 17) in high yields ( $85 \%$ and $80 \%$ respectively).

\subsection{Biological Testing}

\subsubsection{Evaluation of Compounds 10, 11, 16 and $\mathbf{1 7}$ at $20 \mu \mathrm{M}$ in P. aeruginosa Biofilms}

Previously, our work has demonstrated that nitroxides can trigger dispersal events in pre-formed P. aeruginosa biofilms [27]. In addition to this, we have also shown that combined treatment with the nitroxide 4-carboxy-2,2,6,6-tetramethylpiperidin-1-yloxyl (CTEMPO) (at $20 \mu \mathrm{M})$ and the antibiotic ciprofloxacin 2 (at its MIC of $320 \mathrm{ng} / \mathrm{mL}(0.97 \mu \mathrm{M})$ ) can result in almost complete eradication of mature P. aeruginosa and E. coli biofilms in a flow cell assay [31]. Here, we employed a similar approach involving pre-formed P. aeruginosa biofilms grown in flow cell chambers to evaluate the dispersal and eradication properties of the prepared ciprofloxacin-nitroxide compounds 10, 11, 16 and 17. P. aeruginosa biofilms were formed in flow cell chambers for $48 \mathrm{~h}$ and then treated with $20 \mu \mathrm{M}$ solutions of the hybrid compounds 10, 11, 16 and $\mathbf{1 7}$ (dissolved in DMSO and delivered into the BM2 minimal medium supplemented with $0.4 \%$ of glucose) for $24 \mathrm{~h}$. This specific concentration was chosen as it was previously established to be the most effective concentration for nitroxide-mediated biofilm dispersal [27]. To aid in the visualization of the resulting biofilms the Live/Dead BacLight bacterial viability kit coupled with confocal microscopy was utilised and provided the images shown in Figure 5 . From these images, the percentages of biofilm biomass eradicated using compounds 10, 11, 16 and 17 relative to the biomass of untreated 2-day-old biofilms were calculated and are displayed in Table 1 . The values for the total live biofilm biomass eradication were calculated by adding the amount of dead cells remaining in the biofilm biomass to the initially eradicated biomass (i.e., compound $\mathbf{1 0}$ had initially $80 \%$ eradicated biomass but as $50 \%$ of the remaining $20 \%$ of biomass was dead, the total live biofilm biomass eradication was $90 \%$ ). As a comparison, we observed little change in biofilm thickness 
by confocal laser scanning microscopy from the treatment of $P$. aeruginosa biofilms with ciprofloxacin alone (at $320 \mathrm{ng} / \mathrm{mL}$ ) in our previous work [31].

Table 1. P. aeruginosa PA14 biofilm biomass eradication values for 2-day-old biofilms treated with compounds 10, 11, 16 and 17 at $20 \mu \mathrm{M}$ relative to the biomass of untreated 2-day-old biofilms.

\begin{tabular}{cccc}
\hline Compound & $\begin{array}{c}\text { Remaining } \\
\text { Biomass (\%) }\end{array}$ & $\begin{array}{c}\text { Dead Cells in } \\
\text { Remaining Biomass (\%) }\end{array}$ & $\begin{array}{c}\text { Total Live Biofilm } \\
\text { Biomass Eradication (\%) }\end{array}$ \\
\hline Control PA14 & - & 4 & - \\
$\mathbf{1 0}$ & 20 & 50 & 90 \\
$\mathbf{1 1}$ & 70 & 5 & 34 \\
$\mathbf{1 6}$ & 37 & 32 & 75 \\
$\mathbf{1 7}$ & 38 & 23 & 71 \\
\hline
\end{tabular}
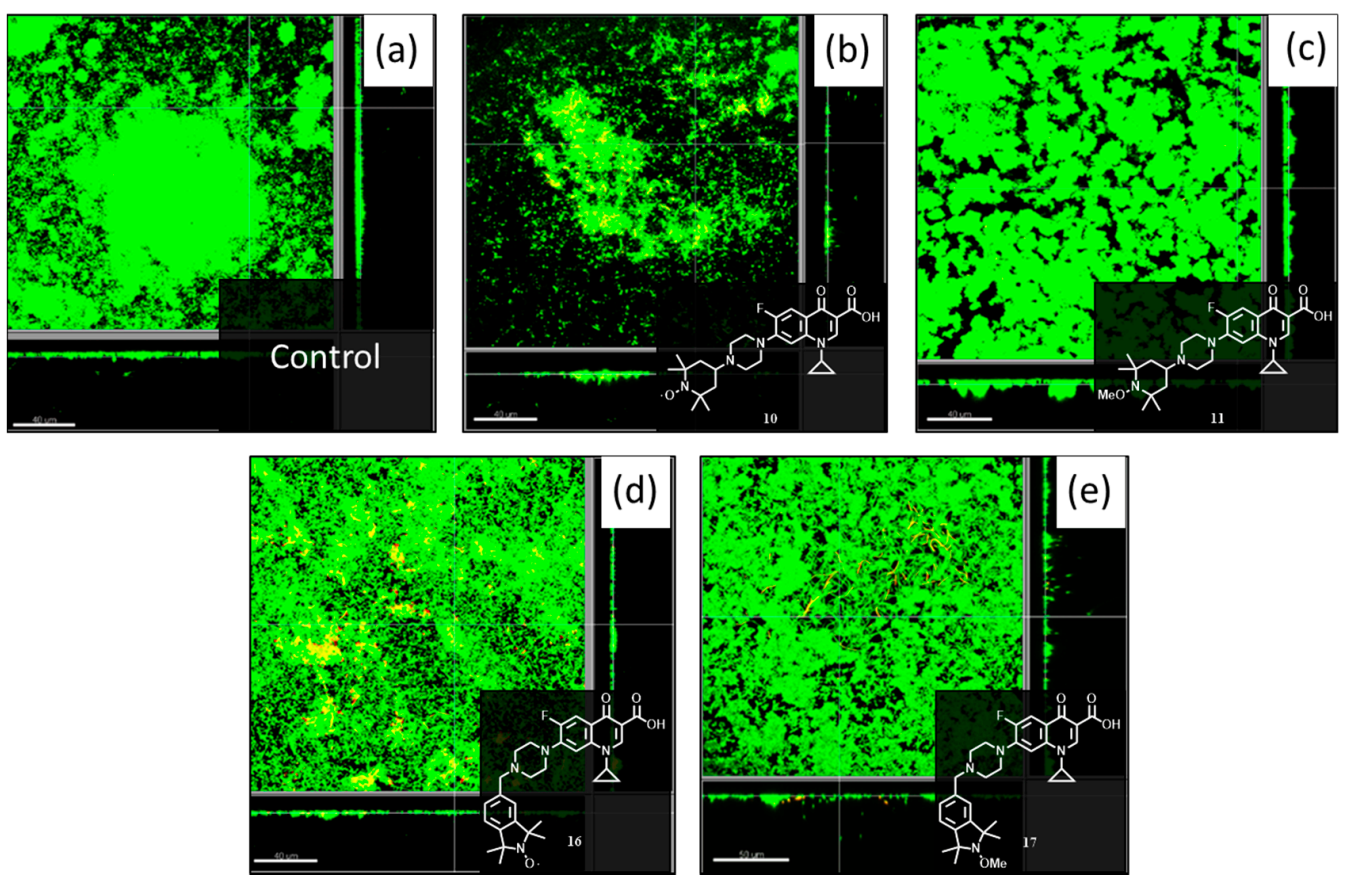

Figure 5. Confocal laser scanning microscopy images of 2 day old pre-formed P. aeruginosa PA14 biofilms grown in a flow cell at $37^{\circ} \mathrm{C}$, treated with $20 \mu \mathrm{M}$ of (b) 10; (c) 11; (d) 16; (e) 17 for $24 \mathrm{~h}$ and then visualized with SYTO-9 (stains live cells green) and propidium iodide (stains dead cells red, merged colors appear as yellow to red). Panel (a) shows an untreated P. aeruginosa PA14 biofilms after 3 days. The scale bars represent $40 \mu \mathrm{m}$ in length for images (a-c,e), and $50 \mu \mathrm{m}$ for image (d). Each panel also shows the $x y, y z$ and $x z$ dimensions.

The ciprofloxacin-nitroxide 10 and its methoxyamine derivative 11, bearing the TEMPO moieties were examined first. In the presence of $20 \mu \mathrm{M}$ of ciprofloxacin-nitroxide 10, a significant reduction in the total biofilm biovolume ( $80 \%$ ) was observed (Table 1, Figure $5 \mathrm{~b}$ ), however, $50 \%$ of the remaining biofilm biomass was composed of dead cells, which represents an overall reduction of $90 \%$ in live cell volume when compared to the untreated PA14 control (Table 1, Figure 5a). This is fairly consistent with our previous work, where we have observed that CTEMPO alone at $20 \mu \mathrm{M}$ can disperse 2-day-old $P$. aeruginosa biofilms with a $60 \%$ reduction in total biofilm biovolume observed. The combination of CTEMPO at $20 \mu \mathrm{M}$ and ciprofloxacin at $320 \mathrm{ng} / \mathrm{mL}(0.97 \mu \mathrm{M})$ caused a $99.3 \%$ reduction in total biofilm biovolume [31]. The corresponding ciprofloxacin-methoxyamine 11, by comparison, was also able to reduce biofilm biomass by $30 \%$ at the same concentration (Table 1, Figure $5 \mathrm{c}$ ), but only $5 \%$ of the remaining cells were dead in the final sample. This represents a total biofilm biomass reduction of only $34 \%$, almost three times less than the nitroxide bearing conjugate 10 . Dispersal of mature $P$. aeruginosa biofilms by alkoxyamines has been previously observed by others for an ethoxyamine 
derivative in a crystal violet biofilm assay, however they also found the corresponding nitroxide to be more effective at inducing dispersal than the alkoxyamine derivative [28]. The flow cell assay results presented here clearly indicate that compound $\mathbf{1 0}$ possesses both dispersal and antibiotic activity, and this compound is the first example of a dual-action nitroxide-antibiotic hybrid molecule for the treatment of mature $P$. aeruginosa biofilms.

Next the flow cell assay results from the ciprofloxacin-nitroxide compound 16 and its methoxyamine derivative $\mathbf{1 7}$ bearing the isoindoline units were analyzed. Both the nitroxide $\mathbf{1 6}$ and the methoxyamine derivative 17 (Figure 5d,e respectively), appear to trigger some dispersal and subsequent eradication of mature $P$. aeruginosa biofilms at $20 \mu \mathrm{M}$. The degree of eradication observed was slightly better for the nitroxide 16 (75\% total biofilm biomass eradication) than the corresponding methoxyamine 17 (71\% total biofilm biomass eradication), with nitroxide $\mathbf{1 6}$ able to kill a larger proportion of biofilm cells (32\% of dead cells in remaining biomass) than the methoxyamine derivative 17 (23\% of dead cells in remaining biomass). Overall, the best anti-biofilm agent at $20 \mu \mathrm{M}$ was the hybrid compound 10, which contains the TEMPO nitroxide unit. This result is consistent with our previous observation, which showed a higher degree of $P$. aeruginosa biofilm dispersal for the smaller TEMPO-based nitroxide over its isoindoline counterpart [27].

\subsubsection{Evaluation of Compounds 10, 11, 16 and 17 at $40 \mu \mathrm{M}$ in P. aeruginosa Biofilms}

Although compounds 10, 11, 16 and 17 demonstrated biofilm eradication capabilities at a concentration of $20 \mu \mathrm{M}$, the anti-biofilm effects of the prepared compounds were also examined at the higher concentration of $40 \mu \mathrm{M}$. Treatment of 2 day old P. aeruginosa biofilms with compounds 10, 11, 16 and 17 at $40 \mu \mathrm{M}$ for $24 \mathrm{~h}$ gave the images shown in Figure 6 (visualization was undertaken as previously described) from which values for eradication of the biofilm biomass could be calculated (Table 2). For this series of experiments, the viability of the dispersed cells was also quantified by collecting effluent from hybrid- and control- treated flow cells and is summarized in Figure 7.
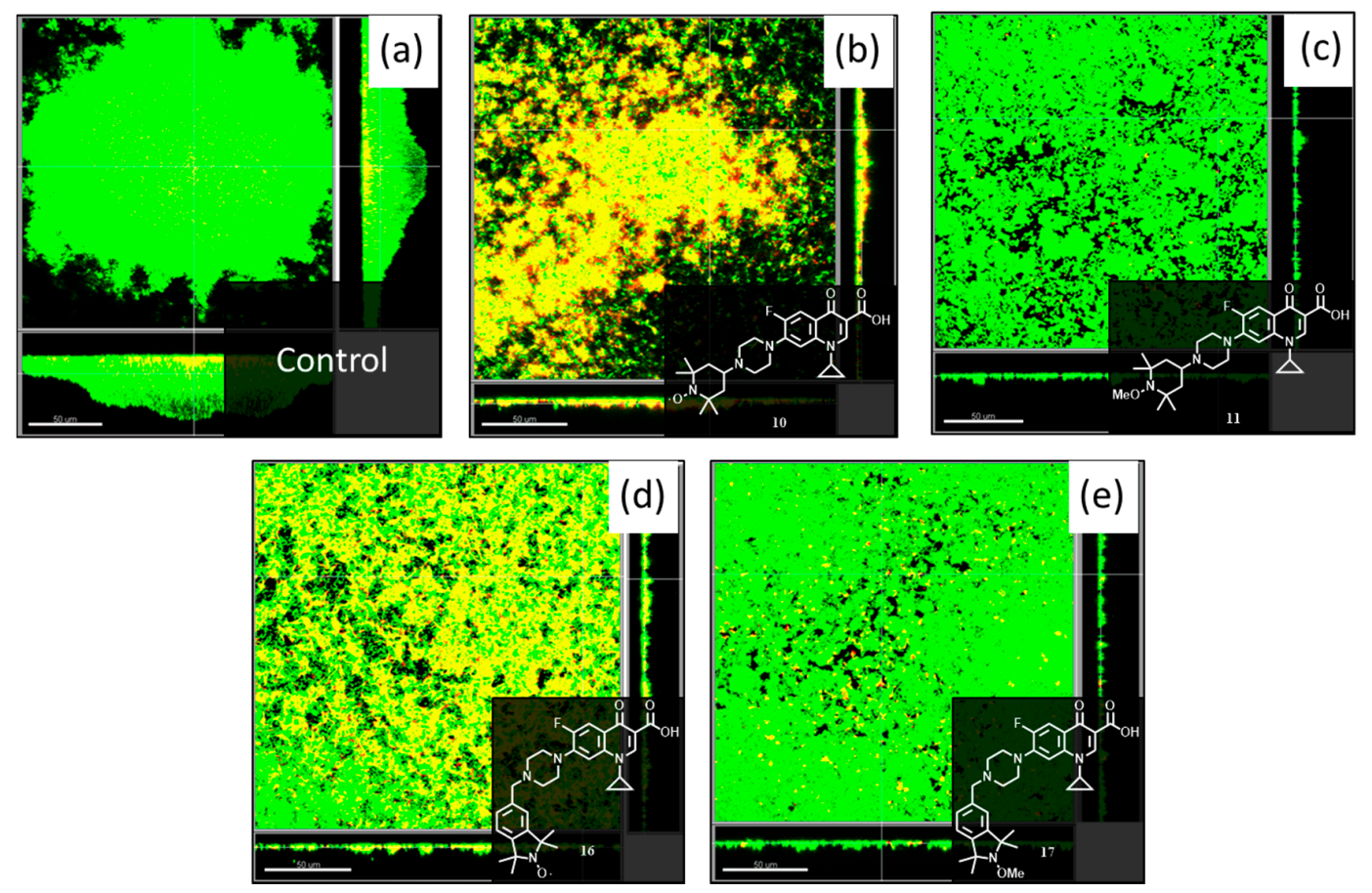

Figure 6. Confocal laser scanning microscopy images of 2 day old pre-formed P. aeruginosa PA14 biofilms grown in a flow cell at $37^{\circ} \mathrm{C}$, treated with $40 \mu \mathrm{M}$ of (b) 10; (c) 11; (d) 16; (e) 17 for $24 \mathrm{~h}$ and then visualized with SYTO-9 (stains live cells green) and propidium iodide (stains dead cells red, merged colors appear as yellow to red). Panel (a) shows an untreated P. aeruginosa PA14 biofilms after 3 days. The scale bars represent $50 \mu \mathrm{m}$ in length for images (a-d). Each panel also shows the xy, yz and xz dimensions. 


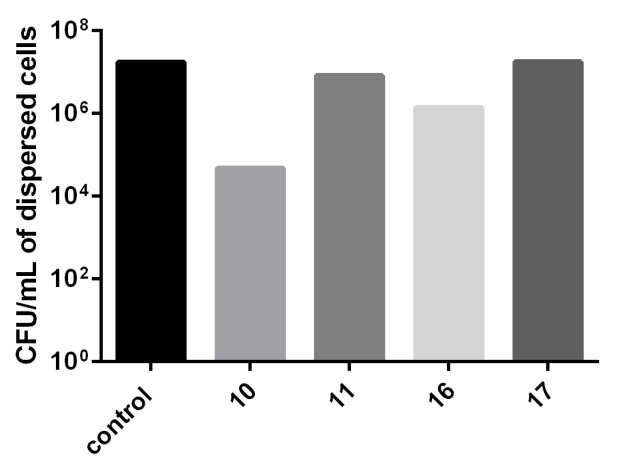

Figure 7. Flow cell effluent harvested from preformed P. aeruginosa PA14 biofilms treated with $40 \mu \mathrm{M}$ of compounds 10, 11, 16, and 17 after $24 \mathrm{~h}$. Bacteria were plated for enumeration.

Table 2. P. aeruginosa PA14 biofilm biomass eradication values for 2-day-old biofilms treated with compounds 10, 11, 16 and 17 at $40 \mu \mathrm{M}$ relative to the biomass of untreated 2-day-old biofilms.

\begin{tabular}{cccc}
\hline Compound & $\begin{array}{c}\text { Remaining } \\
\text { Biomass (\%) }\end{array}$ & $\begin{array}{c}\text { Dead Cells in } \\
\text { Remaining Biomass (\%) }\end{array}$ & $\begin{array}{c}\text { Total Live Biofilm } \\
\text { Biomass Eradication (\%) }\end{array}$ \\
\hline Control PA14 & - & 4 & - \\
$\mathbf{1 0}$ & 59 & 91 & 95 \\
$\mathbf{1 1}$ & 65 & 7 & 40 \\
$\mathbf{1 6}$ & 52 & 64 & 81 \\
$\mathbf{1 7}$ & 52 & 27 & 62 \\
\hline
\end{tabular}

Examination of the anti-biofilm activities of ciprofloxacin-nitroxide $\mathbf{1 0}$ and its methoxyamine conjugate 11 (bearing the TEMPO moieties), revealed that in the presence of $40 \mu \mathrm{M}$ of hybrid 10, a smaller reduction in total biofilm biovolume (41\%) was observed, compared to ciprofloxacin-nitroxide 10 at $20 \mu \mathrm{M}$ (80\% biofilm reduction) (Figure 6b). However, for compound $\mathbf{1 0}$ at $40 \mu \mathrm{M}$, of the $59 \%$ remaining biomass, $91 \%$ was composed of dead cells, which corresponds to an overall reduction of $95 \%$ in live cell volume (a 5\% improvement over compound 10 at $20 \mu \mathrm{M}$ ) when compared to the untreated PA14 control (Figure 6a). This result indicates that higher doses of hybrid compound 10 increased the potency of the compound against mature P. aeruginosa biofilms, but that removal of the majority of dead biofilm biomass in the flow cell did not occur. We speculate that this dead biomass contains various released cytoplasmic components (i.e., DNA) which contribute to its heightened adhesion in the flow cell. Nevertheless, fewer viable dispersed cells were collected from biofilms treated with compound $\mathbf{1 0}$ as compared to untreated biofilms or biofilms treated with all other compounds (Figure 7), reinforcing the potency of this hybrid. Interestingly, the methoxyamine derivative $\mathbf{1 1}$ performed only marginally better at a concentration of $40 \mu \mathrm{M}$ (Figure 6c) than $20 \mu \mathrm{M}$ (values of $40 \%$ and $34 \%$ respectively for total biofilm biomass eradication), which further demonstrates the fundamental importance of the nitroxide moiety to the anti-biofilm activity of hybrid compound $\mathbf{1 0}$. Consistent with the minimal dead biomass, compound $\mathbf{1 1}$ did not affect the viability of dispersed bacteria (Figure 7).

Lastly, the effects of ciprofloxacin-nitroxide $\mathbf{1 6}$ and its methoxyamine conjugate $\mathbf{1 7}$ (containing the isoindoline moiety) in mature P. aeruginosa biofilms were analyzed at the higher concentration of $40 \mu \mathrm{M}$. Both the nitroxide bearing compound $\mathbf{1 6}$ and its methoxyamine derivative $\mathbf{1 7}$ reduced the biofilm biomass volume by the same amount (48\%) (Figure 6d,e respectively), which was less than compounds 16 and 17 at $20 \mu \mathrm{M}$ (63\% and 62\% respectively). However, the increased concentration $(40 \mu \mathrm{M})$ improved the potency of compound 16 by increasing the total biofilm biomass eradication from $75 \%(20 \mu \mathrm{M})$ to $81 \%(40 \mu \mathrm{M})$. Comparatively, the methoxyamine conjugate 17 was only able to reduce the living cell population to $62 \%$, which was less than the nitroxide containing compound $\mathbf{1 6}$. Consistent with these findings, fewer viable dispersed cells were recovered from PA14 biofilms treated 
with compound 16 as compared to compound 17. In general, biofilm eradication was not considerably enhanced at the higher concentration of hybrid molecules, however, the percentage of dead biofilm mass for each respective compound was greater. Future investigations will examine in more detail the observed anti-biofilm effects of ciprofloxacin-nitroxide conjugate molecules.

\section{Experimental Section}

\subsection{General Procedures}

Reactions of an air-sensitive nature were carried out under an atmosphere of ultra-high purity argon. Where anhydrous THF, DMF, DCM or acetonitrile are documented, these solvents were obtained from a Puresolv Micro Multi Unit solvent purification system (Innovative Technologies Amesbury, MA, USA). Anhydrous toluene was dried by storage over sodium wire. Triethylamine and $i$ - $\operatorname{Pr}_{2} \mathrm{NEt}$ were stored over potassium hydroxide. All other reagents were purchased from commercial suppliers and used without further purification. All ${ }^{1} \mathrm{H}-\mathrm{NMR}$ spectra were recorded at either 400 or $600 \mathrm{MHz}$ on either a Varian Inova 400 spectrometer (Varian, Palo Alto, CA, USA), a Bruker Avance 400 spectrometer (Bruker, Billerica, MA, USA) or a Bruker Avance 600 spectrometer. All ${ }^{13}$ C-NMR spectra were recorded at either 100 or 150 on either a Varian Inova 400, a Bruker Avance 400 or a Bruker Avance 600 instrument. Samples were prepared in $\mathrm{CDCl}_{3}$, unless otherwise stated, using oven dried glassware. ${ }^{1} \mathrm{H}-\mathrm{NMR}$ spectra in $\mathrm{CDCl}_{3}$ were referenced to the solvent peak at $7.27 \mathrm{ppm} .{ }^{13} \mathrm{C}-\mathrm{NMR}$ spectra run in $\mathrm{CDCl}_{3}$ were referenced to the solvent peak at $77.2 \mathrm{ppm}$. Coupling constants are reported in $\mathrm{Hz}$. High-resolution ESI mass spectra were obtained with an Agilent Q-TOF LC mass spectrometer (Agilent Technologies, Santa Clara, CA, USA) or a Thermo Fisher Scientific Orbitrap Elite mass spectrometer (Thermo Fisher Scientific, Waltham, MA, USA), which both utilised electrospray ionization in positive ion mode. Fourier transform infrared (FTIR) spectra were recorded on a Nicolet 870 Nexus Fourier Transform Infrared Spectrometer (Thermo Fisher Scientific) equipped with a DTGS TEC detector and an ATR objective. Melting points were measured with a Variable Temperature Apparatus by the capillary method and are uncorrected. Analytical HPLC was carried out on an Agilent Technologies HP 1100 Series HPLC system using an Agilent C18 column $(4.6 \times 250 \mathrm{~mm}, 5 \mu \mathrm{m})$ or an Agilent Zorbax RX-SIL column $(4.6 \times 250 \mathrm{~mm}, 5 \mu \mathrm{m})$ with a flow rate of $1 \mathrm{~mL} / \mathrm{min}$. The purity of all final compounds was determined to be $95 \%$ or higher using HPLC analysis. EPR spectra were obtained with the aid of a miniscope MS 400 Magnettech EPR spectrometer (Magnettech GmbH, Berlin, Germany). Column chromatography was performed using LC60A 40-63 Micron DAVISIL silica gel (Grace, Columbia, MD, USA). Thin-layer chromatography (TLC) was performed on Silica Gel 60 F254 plates (Merck, Billerica, MA, USA). TLC plates were visualised under a UV lamp (254 nm) and/or by visualization with phosphomolybdic acid (PMA).

\subsection{Materials}

Ethyl 1-cyclopropyl-6-fluoro-4-oxo-7-(piperazin-1-yl)-1,4-dihydroquinoline-3-carboxylate 5 [44], 1-methoxy-2,2,6,6-tetramethyl-4-piperidinone 7 [51] and 5-formyl-2-methoxy-1,1,3,3-tetramethylisoindoline 12 [49] were prepared according to known procedures.

\subsection{Biofilm Dispersal Flow Cell Assays}

P. aeruginosa PA14 biofilms were pre-formed at $37^{\circ} \mathrm{C}$ over $48 \mathrm{~h}$ in flow chambers using previously established techniques [27]. The biofilms were then exposed for $24 \mathrm{~h}$ to 20 or $40 \mu \mathrm{M}$ solutions of ciprofloxacin-nitroxide hybrid compounds 10, 11, 16 and 17 resuspended in DMSO in the flow cell chambers with channel dimensions of $1 \times 4 \times 40 \mathrm{~mm}$. Flow chambers were inoculated with $400 \mu \mathrm{L}$ of an overnight $P$. aeruginosa PA14 culture diluted to an $\mathrm{OD}_{600}$ of $\sim 0.05$. Next, chambers were left without flow for $2 \mathrm{~h}$, after which medium was pumped through the system at a constant rate of $2.4 \mathrm{~mL} / \mathrm{h}$. Staining and visualization of the resulting biofilms was performed using the Live/Dead BacLight bacterial viability kit (Thermo Fisher Scientific) and an Olympus Fluoview FV1000 confocal laser scanning 
microscope (Olympus, Center Valley, PA, USA). Three-dimensional reconstructions and residue biofilm biovolume calculations were done using Imaris software (Bitplane, Zurich, Switzerland). Untreated control samples were conducted in duplicate while compound-treated samples (at both 20 or $40 \mu \mathrm{M}$ ) were conducted once. Biovolume calculations were taken from three distinct fields of view for each flow cell chamber. Images that corresponded to the medium biovolume values were selected as representative images. To quantify dispersed bacteria, flow cell effluent was captured from flow cells treated with $40 \mu \mathrm{M}$ of compounds 10, 11, 16 and 17 after $24 \mathrm{~h}$. Bacteria were plated for enumeration. Enumeration of dispersal cells was conducted once.

\subsection{General Procedure for Reductive Amination, Compounds 8, 9, 14 and 15}

Glacial acetic acid (0.9 equiv.) was added to a solution of ethyl ester protected ciprofloxacin 3 ( 1 equiv.) and the specific ketone/aldehyde bearing compound (1.5 equiv.) in anhydrous methanol under an atmosphere of argon. The resulting solution was stirred at $60{ }^{\circ} \mathrm{C}$ for $2 \mathrm{~h}$ and after cooling to room temperature, $\mathrm{NaBH}_{3} \mathrm{CN}$ (1 equiv.) was added followed by stirring at $50{ }^{\circ} \mathrm{C}$ for 1 day. The reaction mixture was diluted with deionized water $(40 \mathrm{~mL})$, the $\mathrm{pH}$ adjusted to $\sim 7$ using saturated aqueous sodium bicarbonate solution and the mixture extracted with dichloromethane $(3 \times 30 \mathrm{~mL})$. The combined organic extracts were dried over anhydrous sodium sulfate and the solvent was removed in vacuo to afford the crude solid product. Purification was achieved using column chromatography ( $\mathrm{SiO}_{2}$, eluent: 95\% dichloromethane, 5\% methanol).

Ethyl 1-cyclopropyl-6-fluoro-7-(4-(2,2,6,6-tetramethyl-1-oxypiperidine-4-yl)piperazin-1-yl)-4-oxo-1,4-dihydroquinoline3-carboxylate 8: Reagents: 5 (50 mg, $0.14 \mathrm{mmol}, 1$ equiv.), ketone 6 (35 mg, $0.21 \mathrm{mmol}, 1.5$ equiv.), glacial acetic acid $(9 \mu \mathrm{L}, 0.13 \mathrm{mmol}, 0.9$ equiv. $), \mathrm{NaBH}_{3} \mathrm{CN}(8 \mathrm{mg}, 0.14 \mathrm{mmol}, 1$ equiv.) and HPLC grade methanol (10 mL). Data for 8: Light beige powder (37 mg, $0.07 \mathrm{mmol}, 51 \%)$; $\mathrm{mp} 212-222{ }^{\circ} \mathrm{C}$ decomposes. IR (ATR) $v_{\max }\left(\mathrm{cm}^{-1}\right)=1721$ (s, C=O, ester), 1690 (s, C=O, ketone). ${ }^{1} \mathrm{H}-\mathrm{NMR}(600 \mathrm{MHz}$, $\left.\mathrm{CDCl}_{3}\right) \delta=\left({ }^{*}\right.$ note compound is a free-radical, some signals appear broadened and other signals are missing) $\delta=8.59(\mathrm{~s}, 1 \mathrm{H}, \mathrm{NCH}=\mathrm{C}), 8.11(\mathrm{~d}, J=11.6 \mathrm{~Hz}, 1 \mathrm{H}, \mathrm{Ar}-\underline{\mathrm{H}}), 7.36(\mathrm{~s}, 1 \mathrm{H}, \mathrm{Ar}-\underline{\mathrm{H}}), 4.46(\mathrm{q}, J=6.6 \mathrm{~Hz}, 2 \mathrm{H}$, $\mathrm{OCH}_{2} \mathrm{CH}_{3}$ ), 3.51 (br, s, 4H, $2 \times \mathrm{NCH}_{2}$ piperazyl ring), 3.36 (br, s, 1H, C=CHNCH cyclopropyl ring), $2.76\left(\mathrm{br}, \mathrm{s}, 4 \mathrm{H}, 2 \times \mathrm{NCH}_{2}\right.$ piperazyl ring), $1.48\left(\mathrm{t}, J=6.8 \mathrm{~Hz}, 3 \mathrm{H}, \mathrm{OCH}_{2} \mathrm{CH}_{3}\right), 1.32\left(\mathrm{br}, \mathrm{s}, 2 \mathrm{H}, \mathrm{NCHCH}_{2}\right.$ cyclopropyl ring), 1.22 (br, s, $2 \mathrm{H}, \mathrm{NCHCH}_{2}$ cyclopropyl ring). ${ }^{13} \mathrm{C}-\mathrm{NMR}\left(150 \mathrm{MHz}, \mathrm{CDCl}_{3}\right) \delta=172.1$, 164.8, 153.2, 151.6, 147.1, 143.3, 137.0, 122.2, 112.4, 112.2, 109.5, 103.7, 60.3, 59.9, 53.5, 50.3, 48.3, 45.7, 33.6, 24.4, 22.2, 13.4, 7.2 HRMS (ESI): $m / z$ calcd for $\mathrm{C}_{28} \mathrm{H}_{38} \mathrm{FN}_{4} \mathrm{O}_{4}+\mathrm{H}^{+}[\mathrm{M}+\mathrm{H}]^{+}:$514.2955. Found 514.2999. HPLC analysis: retention time $=4.719 \mathrm{~min}$; peak area, $96.30 \%$; eluent $\mathrm{A}$, Methanol; eluent $\mathrm{B}, \mathrm{H}_{2} \mathrm{O}$; isocratic (80:20) over $20 \mathrm{~min}$ with a flow rate of $1 \mathrm{~mL} \mathrm{~min}{ }^{-1}$ and detected at $254 \mathrm{~nm}$; column temperature, rt. EPR: $\mathrm{g}=1.9989, \mathrm{a}_{\mathrm{N}}=1.5750 \mathrm{mT}$.

Ethyl 1-cyclopropyl-6-fluoro-7-(4-(1-methoxy-2,2,6,6-tetramethylpiperidin-4-yl)piperazin-1-yl)-4-oxo-1,4dihydroquinoline-3-carboxylate 9: Reagents: 5 (50 mg, $0.14 \mathrm{mmol}, 1$ equiv.), ketone 7 (35 mg, $0.21 \mathrm{mmol}$, 1.5 equiv.), glacial acetic acid $(9 \mu \mathrm{L}, 0.13 \mathrm{mmol}, 0.9$ equiv. $), \mathrm{NaBH}_{3} \mathrm{CN}(8 \mathrm{mg}, 0.14 \mathrm{mmol}, 1$ equiv.) and HPLC grade methanol (10 mL). Data for 9: White powder (45 mg, $0.09 \mathrm{mmol}, 64 \%)$; $\mathrm{mp} 268-269{ }^{\circ} \mathrm{C}$ decomposed. IR (ATR) $v_{\max }\left(\mathrm{cm}^{-1}\right)=1722$ (s, C=O, ester), 1617 (s, C=O, ketone). ${ }^{1} \mathrm{H}-\mathrm{NMR}(600 \mathrm{MHz}$, $\left.\mathrm{CDCl}_{3}\right) \delta=8.49(\mathrm{~s}, 1 \mathrm{H}, \mathrm{NC} \underline{\mathrm{H}}=\mathrm{C}), 7.98(\mathrm{~d}, J=13.2 \mathrm{~Hz}, 1 \mathrm{H}, \mathrm{Ar}-\underline{\mathrm{H}}), 7.25(\mathrm{~d}, J=7.0 \mathrm{~Hz}, 1 \mathrm{H}, \mathrm{Ar}-\underline{\mathrm{H}}), 4.37(\mathrm{q}$, $\left.J=7.1 \mathrm{~Hz}, 2 \mathrm{H}, \mathrm{OCH}_{2} \mathrm{CH}_{3}\right), 3.61\left(\mathrm{~s}, 3 \mathrm{H}, \mathrm{NOCH}_{3}\right), 3.61(\mathrm{~m}, 1 \mathrm{H}, \mathrm{C}=\mathrm{CHNC} \underline{\mathrm{H}}$ cyclopropyl ring), 3.29 (br, s, $4 \mathrm{H}, 2 \times \mathrm{NCH}_{2}$ piperazyl ring), 2.81 (br, s, 4t $\overline{\mathrm{H}, 2} \times \mathrm{NCH}_{2}$ piperazyl ring), 2.67 (br, s, NC $\mathrm{NCH}_{2} \mathrm{TEMPO}$ ring), $1.68\left(\overline{\mathrm{d}}, \mathrm{J}=11.6 \mathrm{~Hz}, 2 \mathrm{H}, \mathrm{NCHCH}_{2} \mathrm{TEMPO} \operatorname{ring}\right), 1.54\left(\mathrm{t}, J=12.0 \mathrm{~Hz}, 2 \mathrm{H}, \mathrm{NCHCH}_{2} \mathrm{TEMPO}\right.$ ring), 1.39 ( $\left.\mathrm{t}, \mathrm{J}=6.7 \mathrm{~Hz}, 3 \mathrm{H}, \mathrm{OCH}_{2} \mathrm{CH}_{3}\right), 1.30$ (q, $J=6.7 \mathrm{~Hz}, 2 \mathrm{H}, \mathrm{NCHCH}_{2}$ cyclopropyl ring), 1.23 (s, $\left.6 \mathrm{H}, 2 \times \mathrm{CH}_{3}\right), 1.20$ (s, 2H, $\mathrm{NCHCH}_{2}$ cyclopropyl ring), $1.14\left(\mathrm{~s}, 6 \mathrm{H}, 2 \times \mathrm{CH}_{3}\right) .{ }^{13} \mathrm{C}-\mathrm{NMR}(150 \mathrm{MHz}$, $\left.\mathrm{CDCl}_{3}\right) \delta=173.3,166.0,154.4,152.7,148.3,144.7,138.1,123.2,113.4,113.3,110.6,105.0,65.6,63.3$, 61.0, 60.0, 54.8, 50.4, 48.9, 48.4, 41.1, 34.6, 33.5, 33.2, 21.0, 20.8, 14.6, 8.3 HRMS (ESI): $\mathrm{m} / z$ calcd for $\mathrm{C}_{29} \mathrm{H}_{41} \mathrm{FN}_{4} \mathrm{O}+\mathrm{H}^{+}[\mathrm{M}+\mathrm{H}]^{+}:$529.3190. Found 529.3251. HPLC analysis: retention time = $14.443 \mathrm{~min}$; 
peak area, $100 \%$; eluent $\mathrm{A}$, Methanol; eluent $\mathrm{B}, \mathrm{H}_{2} \mathrm{O}$; isocratic (80:20) over 20 min with a flow rate of $1 \mathrm{~mL} \cdot \mathrm{min}^{-1}$ and detected at $254 \mathrm{~nm}$; column temperature, rt.

Ethyl 1-cyclopropyl-6-fluoro-7-(4-(1,1,3,3-tetramethyl-2-oxyisoindolin-5-yl)methyl)piperazin-1-yl)-4-oxo-1,4dihydroquinoline-3-carboxylate 14: Reagents: 5 (70 mg, $0.19 \mathrm{mmol}, 1$ equiv.), aldehyde 12 (63 mg, $0.29 \mathrm{mmol}, 1.5$ equiv.), glacial acetic acid $\left(10 \mu \mathrm{L}, 0.17 \mathrm{mmol}, 0.9\right.$ equiv.), $\mathrm{NaBH}_{3} \mathrm{CN}(12 \mathrm{mg}, 0.19 \mathrm{mmol}$, 1 equiv.) and HPLC grade methanol (10 mL). Data for 14: Light beige powder $(90 \mathrm{mg}, 0.16 \mathrm{mmol}, 82 \%)$; mp 210-211 ${ }^{\circ} \mathrm{C}$. IR (ATR) $v_{\max }\left(\mathrm{cm}^{-1}\right)=1724$ (s, C=O, ester), 1613 (s, C=O, ketone). ${ }^{1} \mathrm{H}-\mathrm{NMR}(600 \mathrm{MHz}$, $\left.\mathrm{CDCl}_{3}\right) \delta=\left({ }^{*}\right.$ note compound is a free-radical, some signals appear broadened and other signals are missing) $\delta=8.57(\mathrm{~s}, 1 \mathrm{H}, \mathrm{NC} \underline{\mathrm{H}}=\mathrm{C}), 8.09(\mathrm{~d}, J=12.7 \mathrm{~Hz}, 1 \mathrm{H}, \mathrm{Ar}-\underline{\mathrm{H}}), 7.32(\mathrm{~s}, 1 \mathrm{H}, \mathrm{Ar}-\underline{\mathrm{H}}), 4.44\left(\mathrm{q}, 2 \mathrm{H}, \mathrm{OCH}_{2} \mathrm{CH}_{3}\right), 4.28$ (br, s, 2H, NCH $\left.\mathrm{H}_{2} \mathrm{Ar}\right), 3.46\left(\mathrm{~m}, 1 \mathrm{H}, \mathrm{C}=\mathrm{CHNCH}\right.$ cyclopropyl ring) 3.38 (br, s, $4 \mathrm{H}, 2 \times \mathrm{NC}^{\mathrm{H}_{2}}$ piperazyl ring), $2.79\left(\mathrm{br}, \mathrm{s}, 4 \mathrm{H}, 2 \times \mathrm{NCH}_{2}\right.$ piperazyl ring), $1.46\left(\mathrm{t}, J=6.8 \mathrm{~Hz}, 3 \mathrm{H}, \mathrm{OCH}_{2} \mathrm{CH}_{3}\right), 1.31(\mathrm{br}, \mathrm{s}, 2 \mathrm{H}$, $\mathrm{NCHCH}_{2}$ cyclopropyl ring), 1.19 (br, s, $2 \mathrm{H}, \mathrm{NCHCH}_{2}$ cyclopropyl ring). ${ }^{13} \mathrm{C}-\mathrm{NMR}\left(150 \mathrm{MHz}, \mathrm{CDCl}_{3}\right)$ $\delta=172.3,165.1,153.8,151.3,147.3,143.8,137.2,122.2,112.6,112.4,109.6,103.9,60.1,60.0,49.2,33.8$, 13.6, 7.4. HRMS (ESI): $m / z$ calcd for $\mathrm{C}_{32} \mathrm{H}_{38} \mathrm{FN}_{4} \mathrm{O}_{4}+\mathrm{H}^{+}[\mathrm{M}+\mathrm{H}]^{+}:$562.2950. Found 562.2950. HPLC analysis: retention time $=3.099$ min; peak area, $99.70 \%$; eluent A, Methanol; over 20 min with a flow rate of $1 \mathrm{~mL} \cdot \mathrm{min}^{-1}$ and detected at $254 \mathrm{~nm}$; column temperature, rt. EPR: $\mathrm{g}=1.9968, \mathrm{a}_{\mathrm{N}}=1.5657 \mathrm{mT}$.

Ethyl 1-cyclopropyl-6-fluoro-7-((4-(2-methoxy-1,1,3,3-tetramethylisoindoline-5-yl)methyl)piperazin-1-yl)-4oxo-1,2,3,4-tetrahydroquinoline-3-carboxylate 15: Reagents: 5 (70 mg, $0.19 \mathrm{mmol}, 1$ equiv.), aldehyde 13 ( $68 \mathrm{mg}, 0.29 \mathrm{mmol}, 1.5$ equiv.), glacial acetic acid (10 $\mu \mathrm{L}, 0.17 \mathrm{mmol}, 0.9$ equiv.), $\mathrm{NaBH}_{3} \mathrm{CN}(12 \mathrm{mg}$, $0.19 \mathrm{mmol}, 1$ equiv.) and HPLC grade methanol $(10 \mathrm{~mL})$. Data for 15: White powder $(99 \mathrm{mg}, 0.17 \mathrm{mmol}$, 90\%); mp 191-192 ${ }^{\circ} \mathrm{C}$. IR (ATR) $v_{\max }\left(\mathrm{cm}^{-1}\right)=1721$ (s, C=O, ester), 1615 (s, C=O, ketone). ${ }^{1} \mathrm{H}-\mathrm{NMR}$ $\left(600 \mathrm{MHz}, \mathrm{CDCl}_{3}\right) \delta=8.51(\mathrm{~s}, 1 \mathrm{H}, \mathrm{NC} \underline{\mathrm{H}}=\mathrm{C}), 8.02(\mathrm{~d}, J=13.3 \mathrm{~Hz}, 1 \mathrm{H}, \mathrm{Ar}-\underline{\mathrm{H}}), 7.23(\mathrm{~m}, 2 \mathrm{H}, \mathrm{Ar}-\underline{\mathrm{H}}), 7.05(\mathrm{~m}$, $2 \mathrm{H}, \mathrm{Ar}-\underline{\mathrm{H}}), 4.38\left(\mathrm{q}, J=7.1 \mathrm{~Hz}, 2 \mathrm{H}, \mathrm{OCH}_{2} \mathrm{CH}_{3}\right), 3.79\left(\mathrm{~s}, 3 \mathrm{H}, \mathrm{NOCH}_{3}\right), 3.59\left(\mathrm{~s}, 2 \mathrm{H}, \mathrm{NCH}_{2} \mathrm{Ar}\right), 3.41(\mathrm{~m}, 1 \mathrm{H}$, $\mathrm{C}=\mathrm{CHNC} \underline{\mathrm{H}}$ cyclopropyl ring), $3.29\left(\mathrm{~s}, \overline{\mathrm{H}}, 2 \times \mathrm{NCH}_{2}\right.$ piperazyl $\left.\overline{\operatorname{ring}}\right), 2.67\left(\mathrm{~s}, 4 \mathrm{H}, 2 \times \mathrm{NCH}_{2}\right.$ piperazyl ring), $1.44\left(\mathrm{br}, \mathrm{s}, 12 \mathrm{H}, 4 \times \mathrm{CH}_{3}\right), 1.41\left(\mathrm{t}, J=7.1 \overline{\mathrm{Hz}}, \mathrm{OCH}_{2} \mathrm{CH}_{3}\right), 1.29\left(\mathrm{~m}, 2 \mathrm{H}, \mathrm{NCHCH} \mathrm{H}_{2}\right.$ cyclopropyl ring), $1.13\left(\mathrm{~m}, 2 \mathrm{H}, \mathrm{NCHCH}_{2}\right.$ cyclopropyl ring). ${ }^{13} \mathrm{C}-\mathrm{NMR}\left(\overline{100 \mathrm{MHz}}, \mathrm{CDCl}_{3}\right) \delta=173.4,166.1,148.3$, 145.5, 144.9, 144.5, 138.2, 136.9, 128.4, 123.2, 123.1, 122.4, 121.5, 113.6, 113.3, 110.6, 104.8, 67.2, 67.1, 65.7, 63.3, 61.1, 53.0, 50.2, 34.6, 14.6, 8.3. HRMS (ESI): $m / z$ calcd for $\mathrm{C}_{33} \mathrm{H}_{41} \mathrm{FN}_{4} \mathrm{O}_{4}+\mathrm{H}^{+}[\mathrm{M}+\mathrm{H}]^{+}: 577.3185$. Found 577.3186. HPLC analysis: retention time $=4.092 \mathrm{~min}$; peak area, $100 \%$; eluent A, Methanol; over $20 \mathrm{~min}$ with a flow rate of $1 \mathrm{~mL} \cdot \mathrm{min}^{-1}$ and detected at $254 \mathrm{~nm}$; column temperature, rt.

\subsection{General Procedure for Ester Hydrolysis, Compounds 10, 11, 16 and 17}

Aqueous sodium hydroxide ( $2 \mathrm{M}, 7$ equiv.) was added to a solution of the specific ethyl ester (1 equiv.) in HPLC grade methanol and the resulting solution was stirred at $50{ }^{\circ} \mathrm{C}$ for $5 \mathrm{~h}$. The reaction mixture was cooled to room temperature and diluted with deionized water $(50 \mathrm{~mL})$. The $\mathrm{pH}$ was adjusted to $\sim 6$ using aqueous hydrochloric acid solution $(2 \mathrm{M})$ and the mixture extracted with dichloromethane $(3 \times 20 \mathrm{~mL})$. The combined organic extracts were dried over anhydrous sodium sulfate and the solvent was removed in vacuo to afford the pure solid product.

1-Cyclopropyl-6-fluoro-7-(4-(2,2,6,6-tetramethyl-1-oxypiperidin-4-yl)piperazin-1-yl)-4-oxo-1,4-dihydroquinoline3-carboxylic acid 10: Reagents: 8 ( $22 \mathrm{mg}, 0.04 \mathrm{mmol}, 1$ equiv.), $2 \mathrm{M}$ aqueous $\mathrm{NaOH}(0.1 \mathrm{~mL}, 0.2 \mathrm{mmol}$, 7 equiv.) and HPLC grade methanol ( $2.5 \mathrm{~mL})$. Data for 10: Light yellow powder $(17 \mathrm{mg}, 0.035 \mathrm{mmol}$, $89 \%$ ); mp. $207-208^{\circ} \mathrm{C}$, decomposes. IR (ATR) $v_{\max }\left(\mathrm{cm}^{-1}\right)=3100-2500(\mathrm{w}, \mathrm{br}, \mathrm{O}-\mathrm{H}, \mathrm{COOH}) .{ }^{1} \mathrm{H}-\mathrm{NMR}$ $\left(600 \mathrm{MHz}, \mathrm{CDCl}_{3}\right) \delta=\left({ }^{*}\right.$ note compound is a free-radical, some signals appear broadened and other signals are missing) $14.93(\mathrm{~s}, 1 \mathrm{H}, \mathrm{COO} \underline{\mathrm{H}}), 8.83(\mathrm{~s}, 1 \mathrm{H}, \mathrm{NC} \underline{\mathrm{H}}=\mathrm{C}), 8.07(\mathrm{~d}, J=10.7 \mathrm{~Hz}, 1 \mathrm{H}, \mathrm{Ar}-\underline{\mathrm{H}}), 7.47(\mathrm{~s}, 1 \mathrm{H}$,

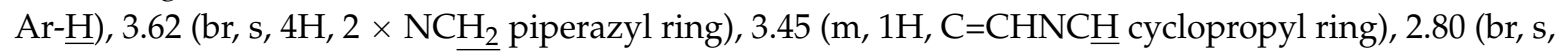
$4 \mathrm{H}, 2 \times \mathrm{NCH}_{2}$ piperazyl ring), 1.50 (br, s, 2H, $\mathrm{NCHCH}_{2}$ cyclopropyl ring), 1.31 (br, s, 2H, $\mathrm{NCHCH}_{2}$ cyclopropyl ring). ${ }^{13} \mathrm{C}-\mathrm{NMR}\left(150 \mathrm{MHz}, \mathrm{CDCl}_{3}\right) \delta=\overline{175.5}, 165.5,153.0,151.3,145.9,144.2,137.6,118.3$, 
$110.9,110.8,106.6,103.3,47.7,45.1,34.1,28.2,6.9$. HRMS (ESI): $m / z$ calcd for $\mathrm{C}_{26} \mathrm{H}_{34} \mathrm{FN}_{4} \mathrm{O}_{4}+\mathrm{H}^{+}$ $[\mathrm{M}+\mathrm{H}]^{+}:$486.2642. Found 486.2659. HPLC analysis: retention time $=4.569 \mathrm{~min}$; peak area, $100 \%$; eluent A, DCM; eluent B, THF; isocratic (70:30) over 20 min with a flow rate of $1 \mathrm{~mL} \mathrm{~min}-1$ and detected at $254 \mathrm{~nm}$; column temperature, rt. EPR: $\mathrm{g}=1.9989, \mathrm{a}_{\mathrm{N}}=1.5750 \mathrm{mT}$.

1-Cyclopropyl-6-fluoro-7-(4-(1-methoxy-2,2,6,6-tetramethylpiperidin-4-yl)piperazin-1-yl)-4-oxo-1,4-dihydroquinoline3-carboxylic acid 11: Reagents: 9 (20 mg, $0.04 \mathrm{mmol}, 1$ equiv.), $2 \mathrm{M}$ aqueous $\mathrm{NaOH}(0.1 \mathrm{~mL}, 0.2 \mathrm{mmol}$, 7 equiv.) and HPLC grade methanol (2.5 mL). Data for 11: White powder (17 mg, $0.03 \mathrm{mmol}, 85 \%)$; mp 230-232 ${ }^{\circ} \mathrm{C}$, decomposes. IR (ATR) $v_{\max }\left(\mathrm{cm}^{-1}\right)=3100-2500(\mathrm{w}, \mathrm{br}, \mathrm{O}-\mathrm{H}, \mathrm{COOH}) .{ }^{1} \mathrm{H}-\mathrm{NMR}$ $\left(600 \mathrm{MHz}, \mathrm{CDCl}_{3}\right) \delta=15.02(\mathrm{~s}, 1 \mathrm{H}, \mathrm{COOH}), 8.74(\mathrm{~s}, 1 \mathrm{H}, \mathrm{NCH}=\mathrm{C}), 7.98(\mathrm{~d}, J=13.0 \mathrm{~Hz}, 1 \mathrm{H}, \mathrm{Ar}-\underline{\mathrm{H}}), 7.35$ $(\mathrm{d}, J=7.0 \mathrm{~Hz}, 1 \mathrm{H}, \mathrm{Ar}-\underline{\mathrm{H}}), 3.61\left(\mathrm{~s}, 3 \mathrm{H}, \mathrm{NOCH}_{3}\right), 3.55(\mathrm{~m}, 1 \mathrm{H}, \mathrm{C}=\mathrm{CHNCH}$ cyclopropyl ring), 3.34 (m, $4 \mathrm{H}, 2 \times \mathrm{NCH}_{2}$ piperazyl ring), $2.79\left(\mathrm{~m}, 4 \overline{\mathrm{H}}, 2 \times \mathrm{NCH}_{2}\right.$ piperazyl ring), $2.75\left(\mathrm{t}, \mathrm{J}=3.3 \mathrm{~Hz}, \mathrm{NC}^{\mathrm{HCH}} \mathrm{H}_{2}\right.$ TEMPO ring), $1.66\left(\mathrm{~d}, J=12.6 \mathrm{~Hz}, 2 \mathrm{H}, \mathrm{NCHCH}_{2}\right.$ TEMPO ring), $1.52\left(\mathrm{t}, J=12.2 \mathrm{~Hz}, 2 \mathrm{H}, \mathrm{NCHCH}_{2}\right.$ TEMPO ring), 1.39 (q, $J=6.5 \mathrm{~Hz}, 2 \mathrm{H}, \mathrm{NCHCH}_{2}$ cyclopropyl ring), $1.23\left(\mathrm{~s}, 6 \mathrm{H}, 2 \times \mathrm{CH}_{3}\right), 1.20(\mathrm{~m}, \overline{\mathrm{H}}$, $\mathrm{NCHCH}_{2}$ cyclopropyl ring), 1.15 (s, $\left.6 \mathrm{H}, 2 \times \overline{\mathrm{CH}}_{3}\right) .{ }^{13} \mathrm{C}-\mathrm{NMR}\left(150 \mathrm{MHz}, \mathrm{CDCl}_{3}\right) \delta=1 \overline{75.5}, 165.5,153.0$, 151.3, 145.9, 144.2, 137.6, 118.3, 111.1, 110.8, 106.6, 103.3, 47.7, 45.1, 34.1, 28.2, 25.4, 6.9. HRMS (ESI): $m / z$ calcd for $\mathrm{C}_{27} \mathrm{H}_{37} \mathrm{FN}_{4} \mathrm{O}_{4}+\mathrm{H}^{+}[\mathrm{M}+\mathrm{H}]^{+}:$501.2877. Found 501.2857. HPLC analysis: retention time $=4.223$ min; peak area, 100\%; eluent A, DCM; eluent B, THF; isocratic (70:30) over 20 min with a flow rate of $1 \mathrm{~mL} \cdot \mathrm{min}^{-1}$ and detected at $254 \mathrm{~nm}$; column temperature, rt.

1-Cyclopropyl-6-fluoro-7-((4-(1,1,3,3-tetramethyl-2-oxyisoindolin-5-yl)methyl)piperazin-1-yl)-4-oxo-1,2,3,4tetrahydroquinoline-3-carboxylic acid 16: Reagents: 14 (50 mg, $0.089 \mathrm{mmol}, 1$ equiv.), $2 \mathrm{M}$ aqueous $\mathrm{NaOH}$ (0.3 mL, $0.62 \mathrm{mmol}, 7$ equiv.) and HPLC grade methanol $(2.5 \mathrm{~mL})$. Data for 16: Yellow powder $(38 \mathrm{mg}$, $0.071 \mathrm{mmol}, 80 \%) ; \operatorname{mp} 230{ }^{\circ} \mathrm{C}$, decomposes. IR (ATR) $v_{\max }\left(\mathrm{cm}^{-1}\right)=3100-2500(\mathrm{w}, \mathrm{br}, \mathrm{O}-\mathrm{H}, \mathrm{COOH})$. ${ }^{1} \mathrm{H}-\mathrm{NMR}\left(600 \mathrm{MHz}, \mathrm{CD}_{2} \mathrm{Cl}_{2}\right.$ ) ( ${ }^{*}$ note compound is a free-radical, some signals appear broadened and other signals are missing) $\delta=13.73(\mathrm{~s}, 1 \mathrm{H}, \mathrm{COOH}), 8.76(\mathrm{~s}, 1 \mathrm{H}, \mathrm{NCH}=\mathrm{C}), 8.03(\mathrm{br}, \mathrm{s}, 1 \mathrm{H}, \mathrm{Ar}-\underline{\mathrm{H}}), 7.42(\mathrm{br}, \mathrm{s}, 1 \mathrm{H}$,

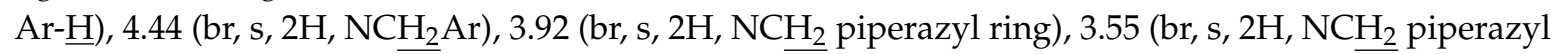
ring), 3.38 (br, s, 2H, $\mathrm{NC}_{\underline{\mathrm{H}}}$ piperazyl ring), 3.14 (s, 1H, C=CHNC $\underline{\mathrm{H}}$ cyclopropyl ring), 2.72 (br, s, $2 \mathrm{H}$, $\mathrm{NCH}_{2}$ piperazyl ring), 1.38 (s, 2H, $\mathrm{NCHCH}_{2}$ cyclopropyl ring), 1.19 (s, 2H, $\mathrm{NCHCH}_{2}$ cyclopropyl ring). ${ }^{13} \mathrm{C}-\mathrm{NMR}\left(150 \mathrm{MHz}, \mathrm{CD}_{2} \mathrm{Cl}_{2}\right) \delta=177.2,35.4$, 8.3. HRMS (ESI): $\mathrm{m} / z$ calcd for $\mathrm{C}_{30} \mathrm{H}_{34} \mathrm{FN}_{4} \mathrm{O}_{4}$ $+\mathrm{H}^{+}[\mathrm{M}+\mathrm{H}]^{+}:$534.2637. Found 534.2639. HPLC analysis: retention time = $3.801 \mathrm{~min}$; peak area, $100 \%$; eluent $\mathrm{A}, \mathrm{CH}_{3} \mathrm{CN}$; eluent $\mathrm{B}, \mathrm{H}_{2} \mathrm{O} / \mathrm{TFA}$ (99:1); isocratic (95:5) over 20 min with a flow rate of $1 \mathrm{~mL} \cdot \mathrm{min}^{-1}$ and detected at $254 \mathrm{~nm}$; column temperature, rt. EPR: $\mathrm{g}=1.9997, \mathrm{a}_{\mathrm{N}}=1.4924 \mathrm{mT}$.

1-Cyclopropyl-6-fluoro-7-((4-(2-methoxy-1,1,3,3-tetramethylisoindolin-5-yl)methyl)piperazin-1-yl)-4-oxo-1,2,3,4tetrahydroquinoline-3-carboxylic acid 17: Reagents: 15 (50 mg, $0.087 \mathrm{mmol}, 1$ equiv.), $2 \mathrm{M}$ aqueous $\mathrm{NaOH}$ (0.30 mL, $0.61 \mathrm{mmol}, 7$ equiv.) and HPLC grade methanol $(2.5 \mathrm{~mL})$. Data for 17: White powder $(40 \mathrm{mg}$, $0.072 \mathrm{mmol}, 83 \%) ; \operatorname{mp} 299{ }^{\circ} \mathrm{C}$, decomposes. IR (ATR) $v_{\max }\left(\mathrm{cm}^{-1}\right)=3100-2500(\mathrm{w}, \mathrm{br}, \mathrm{O}-\mathrm{H}, \mathrm{COOH})$. ${ }^{1} \mathrm{H}-\mathrm{NMR}\left(600 \mathrm{MHz}, \mathrm{CD}_{2} \mathrm{Cl}_{2}\right) \delta=13.45(\mathrm{~s}, 1 \mathrm{H}, \mathrm{COO} \underline{\mathrm{H}}), 8.78(\mathrm{~s}, 1 \mathrm{H}, \mathrm{NC} \underline{\mathrm{H}}=\mathrm{C}), 8.04(\mathrm{~d}, J=12.8 \mathrm{~Hz}, 1 \mathrm{H}$, $\operatorname{Ar}-\underline{\mathrm{H}}), 7.56(\mathrm{~d}, J=7.1 \mathrm{~Hz}, 1 \mathrm{H}, \operatorname{Ar}-\underline{\mathrm{H}}), 7.48(\mathrm{~m}, 2 \mathrm{H}, \mathrm{Ar}-\underline{\mathrm{H}}), 7.22$ (d, J = $12.8 \mathrm{~Hz}, 1 \mathrm{H}, \mathrm{Ar}-\underline{\mathrm{H}}), 4.22(\mathrm{~d}$, $\left.J=4.7 \mathrm{~Hz}, 2 \mathrm{H}, \mathrm{NCH}_{2} \mathrm{Ar}\right), 3.89\left(\mathrm{~m}, 2 \mathrm{H}, \mathrm{NCH}_{2}\right.$ piperazyl ring), $3.79\left(\mathrm{~s}, 3 \mathrm{H}, \mathrm{NOCH}_{3}\right), 3.73\left(\mathrm{~m}, 2 \mathrm{H}, \mathrm{NCH}_{2}\right.$

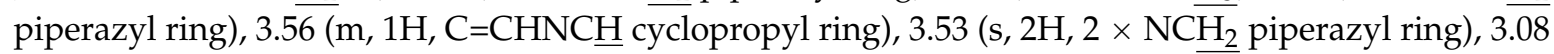
$\left(\mathrm{m}, 2 \mathrm{H}, 2 \times \mathrm{NCH}_{2}\right), 1.55\left(\mathrm{br}, \mathrm{s}, 12 \mathrm{H}, 4 \times \mathrm{CH}_{3}\right), 1.39\left(\mathrm{~m}, 2 \mathrm{H}, 2 \times \mathrm{NCHCH}_{2}\right.$ cyclopropyl ring), $1.18(\mathrm{~m}$, $2 \mathrm{H}, \mathrm{NCHCH}_{2}$ cyclopropyl ring). ${ }^{13} \mathrm{C}-\mathrm{NMR}\left(150 \mathrm{MHz}, \mathrm{CD}_{2} \mathrm{Cl}_{2}\right) \delta=1 \overline{66.9}, 148.5,131.4,125.6,123.0$, 113.1, 107.1, 65.9, 61.7, 51.8, 47.1, 36.1, 8.8. HRMS (ESI): $m / z$ calcd for $\mathrm{C}_{31} \mathrm{H}_{37} \mathrm{FN}_{4} \mathrm{O}_{4}+\mathrm{H}^{+}[\mathrm{M}+\mathrm{H}]^{+}$: 549.2872. Found 549.2870. HPLC analysis: retention time $=4.304 \mathrm{~min}$; peak area, 100\%; eluent $\mathrm{A}$, $\mathrm{CH}_{3} \mathrm{CN}$; eluent $\mathrm{B}, \mathrm{H}_{2} \mathrm{O} / \mathrm{TFA}(99: 1)$; isocratic (95:5) over $20 \mathrm{~min}$ with a flow rate of $1 \mathrm{~mL} \cdot \mathrm{min}^{-1}$ and detected at $254 \mathrm{~nm}$; column temperature, rt. 


\section{Conclusions}

Two ethyl ester protected ciprofloxacin-nitroxide hybrids $\mathbf{8}$ and $\mathbf{1 4}$ together with their methoxyamine analogues $\mathbf{9}$ and 15 were prepared using reductive amination in moderate to high yield (51\%-90\%) from the corresponding ketone or aldehyde bearing nitroxides 6 and 12 or methoxyamines 7 and 13 and the ethyl ester protected ciprofloxacin 5. Base mediated deprotection of 8, 9, 14 and $\mathbf{1 5}$ gave the desired active ciprofloxacin-nitroxides $\mathbf{1 0}$ and $\mathbf{1 6}$ and their control methoxyamines $\mathbf{1 1}$ and 17 in high yield (80\%-90\%). Biological evaluation of hybrid compounds 10, 11, 16 and 17 for anti-biofilm activity against mature $P$. aeruginosa biofilms was performed in a flow cell assay. Both of the ciprofloxacin-nitroxide hybrids were found to have the desired dual-action effect against established biofilms, with the most significant of these being compound 10, which demonstrated both dispersal of $P$. aeruginosa biofilms and eradication (up to $95 \%$ at $40 \mu \mathrm{M}$ ) of the newly dispersed bacteria. In comparison, far less eradication $(40 \%$ at $40 \mu \mathrm{M})$ of the established P. aeruginosa biofilm was observed following treatment with the corresponding methoxyamine 11, suggesting that the nitroxide moiety is key to the effectiveness of analogue 10. The results presented here demonstrate that the combination of an antibiotic and a nitroxide within a single molecule is potentially an effective approach to facilitate the efficient eradication of mature biofilms and thereby overcome the resistance of biofilms to antimicrobials. More detailed investigations into the observed anti-biofilm activities of the ciprofloxacin-nitroxide conjugates are currently in progress and will be reported in due course.

Supplementary Materials: Supplementary materials can be accessed at: http://www.mdpi.com/1420-3049/ 21/7/841/s1.

Acknowledgments: We gratefully acknowledge financial support for this work from the Australian Research Council's Future Fellowship Scheme (FT140100746 to K.E.F.-S.), the Asian Office of Aerospace Research and Development (15IOA087-154020) and Queensland University of Technology. Robert E. W. Hancock acknowledges the Canadian Institutes for Health Research. Sarah C. Mansour received the Centre for Blood Research (CBR) graduate student award as well as the Gerhard Henrik Armauer-Hansen Memorial Scholarship. César de la Fuente-Núñez holds a postdoctoral scholarship from Fundación Ramón Areces (Spain). The mass spectrometry data reported in this paper were obtained at the Central Analytical Research Facility (CARF) operated by the Institute for Future Environments (QUT). Access to CARF is supported by generous funding from the Science and Engineering Faculty (QUT).

Author Contributions: R.E.W.H. and K.E.F.-S. conceived and designed the experiments; A.D.V. and S.C.M. performed the experiments; A.D.V., S.C.M., C.F.-N., R.E.W.H. and K.E.F.-S. analyzed the data; R.E.W.H. and K.E.F.-S. contributed reagents/materials/analysis tools; A.D.V. wrote the paper., S.C.M., C.F.-N., R.E.W.H. and K.E.F.-S. edited the paper.

Conflicts of Interest: The authors declare no conflict of interest

\section{Abbreviations}

The following abbreviations are used in this manuscript:

$\begin{array}{ll}\text { Cyclic di-GMP } & \text { bis- }\left(3^{\prime}-5^{\prime}\right) \text {-cyclic dimeric guanosine monophosphate } \\ \text { DCM } & \text { dichloromethane } \\ \text { DMSO } & \text { dimethyl sulfoxide } \\ \text { DNA } & \text { deoxyribonucleic acid } \\ \text { EPR } & \text { electron paramagnetic resonance } \\ \text { NMR } & \text { nuclear magnetic resonance } \\ \text { NO } & \text { nitric oxide } \\ \text { THF } & \text { tetrahydrofuran } \\ \text { TLC } & \text { solid thin layer chromatography }\end{array}$

\section{References}

1. Costerton, J.W.; Stewart, P.S.; Greenberg, E.P. Bacterial biofilms: A common cause of persistent infections. Science 1999, 284, 1318-1322. [CrossRef] [PubMed]

2. Hall-Stoodley, L.; Costerton, J.W.; Stoodley, P. Bacterial biofilms: From the natural environment to infectious diseases. Nat. Rev. Microbiol. 2004, 2, 95-108. [CrossRef] [PubMed] 
3. Lynch, A.S.; Robertson, G.T. Bacterial and fungal biofilm infections. Annu. Rev. Med. 2008, 59, 415-428. [CrossRef] [PubMed]

4. Vickery, K.; Hu, H.; Jacombs, A.S.; Bradshaw, D.A.; Deva, A.K. A review of bacterial biofilms and their role in device-associated infection. Healthcare Infection 2013, 18, 61-66. [CrossRef]

5. Percival, S.L.; Hill, K.E.; Williams, D.W.; Hooper, S.J.; Thomas, D.W.; Costerton, J.W. A review of the scientific evidence for biofilms in wounds. Wound Repair Regen. 2012, 20, 647-657. [CrossRef] [PubMed]

6. Davies, D. Understanding biofilm resistance to antibacterial agents. Nat. Rev. Drug Discovery 2003, 2, 114-122. [CrossRef] [PubMed]

7. Costerton, J.W.; Cheng, K.J.; Geesey, G.G.; Ladd, T.I.; Nickel, J.C.; Dasgupta, M.; Marrie, T.J. Bacterial biofilms in nature and disease. Annu. Rev. Microbiol. 1987, 41, 435-464. [CrossRef] [PubMed]

8. Lebeaux, D.; Ghigo, J.-M.; Beloin, C. Biofilm-related infections: Bridging the gap between clinical management and fundamental aspects of recalcitrance toward antibiotics. Microbiol. Mol. Biol. Rev. 2014, 78, 510-543. [CrossRef] [PubMed]

9. Luppens, S.B.I.; Reij, M.W.; van der Heijden, R.W.L.; Rombouts, F.M.; Abee, T. Development of a standard test to assess the resistance of Staphylococcus aureus biofilm cells to disinfectants. Appl. Environ. Microbiol. 2002, 68, 4194-4200. [CrossRef] [PubMed]

10. Stewart, P.S.; William Costerton, J. Antibiotic resistance of bacteria in biofilms. Lancet 2001, 358, $135-138$. [CrossRef]

11. McDougald, D.; Rice, S.A.; Barraud, N.; Steinberg, P.D.; Kjelleberg, S. Should we stay or should we go: Mechanisms and ecological consequences for biofilm dispersal. Nat. Rev. Microbiol. 2012, 10, 39-50. [CrossRef] [PubMed]

12. Worthington, R.J.; Richards, J.J.; Melander, C. Non-microbicidal control of bacterial biofilms with small molecules. Anti-Infect. Agents 2014, 12, 120-138. [CrossRef]

13. Bjarnsholt, T.; Ciofu, O.; Molin, S.; Givskov, M.; Hoiby, N. Applying insights from biofilm biology to drug development can a new approach be developed? Nat. Rev. Drug Discov. 2013, 12, 791-808. [CrossRef] [PubMed]

14. Barraud, N.; Storey, M.V.; Moore, Z.P.; Webb, J.S.; Rice, S.A.; Kjelleberg, S. Nitric oxide-mediated dispersal in single- and multi-species biofilms of clinically and industrially relevant microorganisms. Microb. Biotechnol. 2009, 2, 370-378. [CrossRef] [PubMed]

15. Schmidt, I.; Steenbakkers, P.J.M.; Op den Camp, H.J.M.; Schmidt, K.; Jetten, M.S.M. Physiologic and proteomic evidence for a role of nitric oxide in biofilm formation by Nitrosomonas europaea and other ammonia oxidizers. J. Bacteriol. 2004, 186, 2781-2788. [CrossRef] [PubMed]

16. Barraud, N.; Hassett, D.J.; Hwang, S.-H.; Rice, S.A.; Kjelleberg, S.; Webb, J.S. Involvement of nitric oxide in biofilm dispersal of Pseudomonas aeruginosa. J. Bacteriol. 2006, 188, 7344-7353. [CrossRef] [PubMed]

17. Cutruzzolà, F.; Frankenberg-Dinkel, N. Origin and impact of nitric oxide in Pseudomonas aeruginosa biofilms. J. Bacteriol 2016, 198, 55-65. [CrossRef] [PubMed]

18. Chua, S.L.; Liu, Y.; Yam, J.K.H.; Chen, Y.; Vejborg, R.M.; Tan, B.G.C.; Kjelleberg, S.; Tolker-Nielsen, T.; Givskov, M.; Yang, L. Dispersed cells represent a distinct stage in the transition from bacterial biofilm to planktonic lifestyles. Nat. Commun. 2014, 5, 4462. [CrossRef] [PubMed]

19. Liu, N.; Xu, Y.; Hossain, S.; Huang, N.; Coursolle, D.; Gralnick, J.A.; Boon, E.M. Nitric oxide regulation of cyclic di-gmp synthesis and hydrolysis in Shewanella woodyi. Biochemistry 2012, 51, 2087-2099. [CrossRef] [PubMed]

20. Bill Cai, T.; Wang, P.G.; Holder, A.A. NO and NO donors. In Nitric Oxide Donors for Pharmaceutical and Biological Applications; Wang, P.G., Cai, T.B., Taniguchi, N., Eds.; Wiley-VCH: Weinheim, Germany, 2005; Volume 9, pp. 1-31.

21. Arora, D.P.; Hossain, S.; Xu, Y.; Boon, E.M. Nitric oxide regulation of bacterial biofilms. Biochemistry 2015, 54, 3717-3728. [CrossRef] [PubMed]

22. Barraud, N.; Kelso, M.J.; Rice, S.A.; Kjelleberg, S. Nitric oxide: A key mediator of biofilm dispersal with applications in infectious diseases. Curr. Pharm. Des. 2015, 21, 31-42. [CrossRef] [PubMed]

23. Barraud, N.; Kardak, B.G.; Yepuri, N.R.; Howlin, R.P.; Webb, J.S.; Faust, S.N.; Kjelleberg, S.; Rice, S.A.; Kelso, M.J. Cephalosporin-3'-diazeniumdiolates: Targeted NO-donor prodrugs for dispersing bacterial biofilms. Angew. Chem. Int. Ed. Engl. 2012, 51, 9057-9060. [CrossRef] [PubMed] 
24. Wang, P.G.; Cai, T.B.; Taniguchi, N. Nitric Oxide Donors: For Pharmaceutical and Biological Applications; Wiley-VCH: Weinheim, Germany, 2005; Volume 9, p. 390.

25. Likhtenshtein, G.I.; Yamauchi, J.; Nakatsuji, S.I.; Smirnov, A.I.; Tamura, R. Nitroxides; Applications in Chemistry, Biomedicine, and Materials Science; John Wiley \& Sons: New York, NY, USA, 2008; p. 419.

26. Lam, M.A.; Pattison, D.I.; Bottle, S.E.; Keddie, D.J.; Davies, M.J. Nitric oxide and nitroxides can act as efficient scavengers of protein-derived free radicals. Chem. Res. Toxicol. 2008, 21, 2111-2119. [CrossRef] [PubMed]

27. De la Fuente-Núñez, C.; Reffuveille, F.; Fairfull-Smith, K.E.; Hancock, R.E.W. Effect of nitroxides on swarming motility and biofilm formation, multicellular behaviors in Pseudomonas aeruginosa. Antimicrob. Agents Chemother. 2013, 57, 4877-4881. [CrossRef] [PubMed]

28. Alexander, S.-A.; Rouse, E.M.; White, J.M.; Tse, N.; Kyi, C.; Schiesser, C.H. Controlling biofilms oncultural materials: The role of 3-(dodecane-1-thiyl)-4-(hydroxymethyl)-2,2,5,5-tetramethyl-1-pyrrolinoxyl. Chem. Commun. 2015, 51, 3355-3358. [CrossRef] [PubMed]

29. Alexander, S.-A.; Kyi, C.; Schiesser, C.H. Nitroxides as anti-biofilm compounds for the treatment of Pseudomonas aeruginosa and mixed-culture biofilms. Org. Biomol. Chem. 2015, 13, 4751-4759. [CrossRef] [PubMed]

30. Gozdziewska, M.; Cichowicz, G.; Markowska, K.; Zawada, K.; Megiel, E. Nitroxide-coated silver nanoparticles: Synthesis, surface physicochemistry and antibacterial activity. RSC Adv. 2015, 5, 58403-58415. [CrossRef]

31. Reffuveille, F.; de la Fuente-Núñez, C.; Fairfull-Smith, K.E.; Hancock, R.E.W. Potentiation of ciprofloxacin action against gram-negative bacterial biofilms by a nitroxide. Pathog. Dis. 2015, 73. [CrossRef] [PubMed]

32. Drlica, K.; Zhao, X. DNA gyrase, topoisomerase IV, and the 4-quinolones. Microbiol. Mol. Biol. Rev. 1997, 61, 377-392. [PubMed]

33. Campoli-Richards, D.M.; Monk, J.P.; Price, A.; Benfield, P.; Todd, P.A.; Ward, A. Ciprofloxacin. A review of its antibacterial activity, pharmacokinetic properties and therapeutic use. Drugs 1988, 35, 373-447. [CrossRef] [PubMed]

34. Zhi, C.; Long, Z.-Y.; Manikowski, A.; Comstock, J.; Xu, W.-C.; Brown, N.C.; Tarantino, P.M., Jr.; Holm, K.A.; Dix, E.J.; Wright, G.E.; et al. Hybrid antibacterials. DNA polymerase-topoisomerase inhibitors. J. Med. Chem. 2006, 49, 1455-1465. [CrossRef] [PubMed]

35. Patel, R.V.; Park, S.W. Discovery of the highly potent fluoroquinolone-based benzothiazolyl-4-thiazolidinone hybrids as antibacterials. Chem. Biol. Drug Des. 2014, 84, 123-129. [CrossRef] [PubMed]

36. Gootz, T.D.; Brighty, K.E. Fluoroquinolone antibacterials: SAR, mechanism of action, resistance, and clinical aspects. Med. Res. Rev. 1996, 16, 433-486. [CrossRef]

37. Emami, S.; Shafiee, A.; Foroumadi, A. Structural features of new quinolones relationship to antibacterial activity against gram-positive bacteria. Mini-Rev. Med. Chem. 2006, 6, 375-386. [CrossRef] [PubMed]

38. Shindikar, A.V.; Viswanathan, C.L. Novel fluoroquinolones: Design, synthesis, and in vivo activity in mice against Mycobacterium tuberculosis h 37 Rv. Bioorg. Med. Chem. Lett. 2005, 15, 1803-1806. [CrossRef] [PubMed]

39. Sriram, D.; Aubry, A.; Yogeeswari, P.; Fisher, L.M. Gatifloxacin derivatives: Synthesis, antimycobacterial activities, and inhibition of Mycobacterium tuberculosis DNA gyrase. Bioorg. Med. Chem. Lett. 2006, 16, 2982-2985. [CrossRef] [PubMed]

40. Dubar, F.; Anquetin, G.; Pradines, B.; Dive, D.; Khalife, J.; Biot, C. Enhancement of the antimalarial activity of ciprofloxacin using a double prodrug/bioorganometallic approach. J. Med. Chem. 2009, 52, 7954-7957. [CrossRef] [PubMed]

41. Baxter, E.W.; Reitz, A.B. Reductive aminations of carbonyl compounds with borohydride and borane reducing agents. Org. React. 2002, 59, 711-714.

42. Thomas, K.; Chalmers, B.A.; Fairfull-Smith, K.E.; Bottle, S.E. Approaches to the synthesis of a water-soluble carboxy nitroxide. Eur. J. Org. Chem. 2013, 2013, 853-857. [CrossRef]

43. Volodarsky, L.B.; Reznikov, V.A.; Ovcharenko, V.I. Synthetic Chemistry Stable Nitroxides; CRC: Boca Raton, FL, USA, 1994; p. 240.

44. Schmidt, M.; Harmuth, S.; Barth, E.R.; Wurm, E.; Fobbe, R.; Sickmann, A.; Krumm, C.; Tiller, J.C. Conjugation of ciprofloxacin with poly(2-oxazoline)s and polyethylene glycol via end groups. Bioconjugate Chem. 2015, 26, 1950-1962. [CrossRef] [PubMed] 
45. Brandt, S.D.; Moore, S.A.; Freeman, S.; Kanu, A.B. Characterization of the synthesis of N,N-dimethyltryptamine by reductive amination using gas chromatography ion trap mass spectrometry. Drug Test. Anal. 2010, 2, 330-338. [CrossRef] [PubMed]

46. Abdel-Magid, A.F.; Carson, K.G.; Harris, B.D.; Maryanoff, C.A.; Shah, R.D. Reductive amination of aldehydes and ketones with sodium triacetoxyborohydride. Studies on direct and indirect reductive amination procedures. J. Org. Chem. 1996, 61, 3849-3862. [CrossRef] [PubMed]

47. Borch, R.F.; Bernstein, M.D.; Durst, H.D. Cyanohydridoborate anion as a selective reducing agent. J. Am. Chem. Soc. 1971, 93, 2897-2904. [CrossRef]

48. Lane, C.F. Sodium cyanoborohydride, a highly selective reducing agent for organic functional groups. Synthesis 1975, 3, 135-146. [CrossRef]

49. Chalmers, B.A.; Morris, J.C.; Fairfull-Smith, K.E.; Grainger, R.S.; Bottle, S.E. A novel protecting group methodology for syntheses using nitroxides. Chem. Commun. 2013, 49, 10382-10384. [CrossRef] [PubMed]

50. Keddie, D.J.; Johnson, T.E.; Arnold, D.P.; Bottle, S.E. Synthesis of profluorescent isoindoline nitroxides via palladium-catalyzed heck alkenylation. Org. Biomol. Chem. 2005, 3, 2593-2598. [CrossRef] [PubMed]

51. Aubert, M.; Tirri, T.; Wilen, C.-E.; Francois-Heude, A.; Pfaendner, R.; Hoppe, H.; Roth, M. Versatile bis(1-alkoxy-2,2,6,6-tetramethylpiperidin-4-yl)-diazenes (azonors) and related structures and their utilization as flame retardants in polypropylene, low density polyethylene and high-impact polystyrene. Polym. Degrad. Stab. 2012, 97, 1438-1446. [CrossRef]

Sample Availability: Samples of the compounds 10, 11, 16 and 17 are available from the authors.

(C) 2016 by the authors; licensee MDPI, Basel, Switzerland. This article is an open access article distributed under the terms and conditions of the Creative Commons Attribution (CC-BY) license (http://creativecommons.org/licenses/by/4.0/). 